Вестник Новосибирского государственного педагогического университета

2(30)2016 www.vestnik.nspu.ru ISSN 2226-3365

(C) Е. Г. Басалаева

DOI: $10.15293 / 2226-3365.1602 .04$

\title{
УДК 81'371
}

\section{НАЦИОНАЛЬНО-КУЛЬТУРНАЯ СПЕЦИФИКА ЛЕКСИКИ ОБОНЯТЕЛЬНОГО ВОСПРИЯТИЯ*}

\begin{abstract}
Е. Г. Басалаева (Новосибирск, Россия)
В статье анализируются различные способы описания действительности через призму запахового восприятия в интернет-дискурсе. Обонятельное восприятие является одним из важнейших этапов деятельности человеческого сознания по освоению предметного мира. В настоящее время интерес к изучению ольфакторного номинативного пространства возрастает. При этом остаются открытыми вопросы о специфике его национально-культурного своеобразия, закреплении устойчивых запаховых ассоциачий за тем или иным объектом действительности, складываюшихся в некий культурный стереотип. Поэтому в настоящем исследовании на материале текстов, извлеченных из интернет-дискурса, предпринята попытка описать особенности проявления начионально-культурного компонента в одорически маркированных высказываниях относительно «своего» пространства (родины, города, страны и пр.). В результате проведенного анализа можно выявить наиболее стереотипные ольфакторные представления, зависящие от стандартов обонятельной культуры и от собственных представлений говорящего человека. Так, образ родной страны для говорящих оказывается, с одной стороны, положительно окрашенным, что формируется такими запаховыми стереотипами, как запах природы, мороза, хлеба, матери и пр., с другой стороны, негативно оцениваемым, часто за счет метафорических переосмыслений (запах бедности). Одорические образы часто подменяются ментальными, тем самым можно наблюдать два семантических процесса: описание запаха и символизацию обонятельных впечатлений. Таким образом, слова с семой запах участвуют не только в процессе языкового кодирования ситуации ольфакторного восприятия, но и выступают в роли культурно значимых ориентиров, способствующих познанию окружающей действительности.
\end{abstract}

Ключевые слова: лексическая семантика, начионально-культурный компонент, лексика обонятельного восприятия, интернет-дискурс.

По справедливому замечанию исследователей, запах, его восприятие, интерпретация и отношение к нему является культурным, исторически и социально формирующимся феноменом [1, с. 101].
Так, К. Классен указывает на то, что «запахи обладают культурно-релевантными значениями и участвуют в общественной жизни человека» в качестве парадигмы идентификации мира и взаимодействия с ним [2, с. 47-48].

* Статья подготовлена при поддержке РГНФ, грант № 15-04-00122а «Прагматический потенциал языкового знака: семасиологический и лексикографический аспекты».

Басалаева Елена Геннадьевна - кандидат филологических наук, доцент, кафедра теории языка и межкультурной коммуникации, Новосибирский государственный педагогический университет E-mail: lena.bas@mail.ru 
Вестник Новосибирского государственного педагогического университета

\section{2(30)2016}

Эта особенность ольфакторной перцепции человека в первую очередь связана с её субъективно-оценочной сущностью [3]. Индивидуальные особенности восприятия запахов делают лексику, вербализующую запахи, важным источником информации о роли запахов не только в жизни отдельного человека, но и целого этноса. Анализ лексического состава современных языков позволяет исследовать обширный материал, свидетельствующий о закрепленных в национальном сознании ольфакторных образах, стереотипах, предпочтениях. В связи с этим изучение национально обусловленных особенностей одорического восприятия настоящее время приобретает особую актуальность и значимость (О. Вайнштейн [4], Р. Кирсанова [5], К. Классен [2], А. А. Колупаева [6], Н. С. Павлова [7], Н. А. Рогачева [8], Ю. А. Старостина [9], T. А. Трипольская [10]; G. A. Miller, P. N. Johnson-Laird [11], T. Engen [12], H. H. Clark, P. A. Carpenter, M. A. Just [13] и др.).

Исследование национально-культурной специфики является достаточно традиционной проблематикой семантики, связанные с этим задачи решались в рамках различных лингвистических направлений. Еще В. В. Виноградов отмечал, что общечеловеческое, понятийное, логическое содержание в словах обрастает своеобразными формами и смысловыми оттенками национального творчества данного народа [14, с. 29].

В. И. Карасик, во многом опираясь на идеи А. А. Потебни [15], отмечает, что языковые знаки имеют разную степень семиотической глубины в процессе общения: от минимального «ближайшего значения слова» до широкого культурно-исторического фона, связанного с «дальнейшим значением слова» [16]. При этом возможно выявление разных типов лексики: с одной стороны, выделяются слова и выражения, в концентрированном виде выражающие специфический опыт народа, пользующегося языком (сюда относятся имена собственные, культурно-исторические реалии, распространенные аллюзии, прецедентные тексты, слова с эмоциональнооценочным фоном, который осознается именно данным этносом и т.д.), с другой стороны, существует большая группа слов и оборотов, имеющих универсальный характер для человечества в целом. Между национальноспецифической и универсальной частями словаря располагается обширная часть лексики со слабо выраженными культурно-специфическими характеристиками. «Точнее было бы сказать, что для значительного числа слов и выражений конкретного языка национальнокультурный компонент значения является вторичным, проявляется в специальном объяснительном контексте» [16].

Национально-культурный компонент значения, наряду с социальным, оценочным, эмотивным и др., по мнению многих исследователей, включается в состав прагматического, в целом представляющего значение в его отношении к говорящему и слушающему, их целям, фоновым знаниям, пропозициональным установкам - исходным допущениям, намерениям, мнениям, эмоциям, оценкам и пр. [17].

По нашему мнению, лексика обонятельного восприятия обладает различным национально-специфическим потенциалом - от закрепленного, устойчивого до ситуативно-обусловленного. Это связано с тем, что особенность такого вида перцепции, как ольфакторное восприятие, характеризуется ведущей ролью субъективного фактора, т. е. личной включенностью воспринимающего запах человека в процесс восприятия и его субъективным отношением к запаху [3]. В ходе восприятия запахов человек дает им личностную оценку на основе сравнения запаха с неким 
Вестник Новосибирского государственного педагогического университета

2(30)2016 www.vestnik.nspu.ru

ISSN 2226-3365

«эталоном», который различается у разных людей [7]. Но при этом частотность и повторяемость национально-культурных запаховых ассоциаций, возникающих в сознании языкового коллектива, позволяет говорить об относительно закрепленных в культуре данного общества ассоциаций, которые объединяют в себе логические и эмотивные содержания и которые складываются в некий культурный стереотип [18, с. 7].

Основными свойствами стереотипа принято считать:

- использование говорящими признаков и атрибутов, содержащихся в стереотипах, для оценки отнесенности предметов к тому или иному классу на основе семейного сходства;

- наличие когнитивной функции, состоящей в генерализации при упорядочивании информации; аффективной функции (противопоставление «своего» и «чужого»); социальной функции (разграничение «внутригруппового» и «внегруппового», что ведет к социальной категоризации и образованию структур, на которые люди ориентируются в обыденной жизни) [19].

Использование стереотипов происходит нередко автоматически: говорящий, как правило, не только совершенно не задумывается об истории мотивировки, но даже не обращает внимания на то, что некоторые эталонные свойства противоречат эмпирической картине мира [20]. По мнению Ю. Е. Прохорова, «несоответствие стереотипа реальному опыту связано, прежде всего, с тем, что в сознании возникает не реальное отражение действительности, а её образ, соответствующий условиям практики реализации этого явления в определённой общности, опосредованной спецификой деятельности в данной общности» $[21$, с. 73$]$.

В качестве обобщающего подхода к стереотипам в лингвистике можно привести определение, предложенное В. В. Красных: стереотип с точки зрения содержания есть некий фрагмент картины мира, существующий в сознании. Это некоторый образ-представление, это ментальная «картинка», некое устойчивое, минимизированно-инвариантное, обусловленное национально-культурной спецификой представления о предмете или о ситуации [22, с. 179].

Наиболее ярко национальная специфика ольфакторных стереотипов и их вербальных репрезентаций проявляется в высказываниях относительно своего или чужого пространства (дома, родины, города, страны и пр.). Перцептивное переживание нередко становится неотъемлемой чертой национальной идентификации говорящего либо демонстрацией принятия или непринятия чужой культуры.

На материале современной интернеткоммуникации можно выявить одорические признаки того или иного пространства, которые приписывает говорящий стране, городу исходя из своего личного опыта, тем самым эксплицирует свои сложившиеся, личностно и культурно обусловленные стереотипы. В первую очередь все выявленные в интернетдискурсе контексты (из интернет-форумов, дневников, живых журналов и пр.), содержащие запаховый маркер того или иного пространства, следует поделить на две большие группы:

- одорическое впечатление о своем родном городе, стране (России);

- запаховые впечатления о чужом государстве, где человек жил, путешествовал или о котором знает из различных источников.

Запах становится своеобразным идентификатором страны, по которому эта страна может узнаваться (наряду с такими материальными объектами, как церкви, памятники, музей и пр.). Чем частотней одорические ассоци- 
Вестник Новосибирского государственного педагогического университета

2(30)2016 www.vestnik.nspu.ru

ISSN 2226-3365

ации носителей языка с тем или иным пространством, тем в большей степени проявляется их стереотипность. Таким образом, лексические единицы, репрезентирующие семантику одорической «свойственности» - «чуждости», оказываются культурно значимыми, т. к. описываемое значение представляет собой кумуляцию культурного опыта говорящего коллектива.

В настоящей статье остановимся подробнее на наиболее ярких особенностях одорического представления «своего пространства» - образа России - в интернет-коммуникации, тем самым выделим наиболее стереотипные ольфакторные представления, зависящие, с одной стороны, от стандартов обонятельной культуры, с другой, - от собственных представлений говорящего человека.

Так, все типичные и многократно повторяющиеся в примерах запахи России можно классифицировать следующим образом:

1) ароматы природы и ее растительных объектов (леса (березы, ели, сосны, кедра), полыни, реже яблони, земляники, сирени, черемухи; реки и пр. $)^{1}$ : Запахи дремучих и бескрайних лесов, луговых трав и цүветов, запахи русской печи и тихого, умиротворяюцего вечера, с еле сльишимым, малиновым звоном вдалеке ${ }^{2}$; Великая Россия издревле пахла

\footnotetext{
${ }^{1}$ В примерах орфография и пунктуация сохранены.

2 Есть ли свой ЗАПАХ у нашей родины? [Электронный pecypc]. - URL: http://otvet.monavista.ru/ 410216/estsvoj-zapah-nashej-rodiny-vashemu-pahnet-rossiya/ (дата обращения 05.01.2016).

3 Чем по Вашему пахнет Россия [Электронный ресурс]. - URL: http://www.bolshoyvopros.ru/ questions/104852 1-est-li-svoj-zapah-u-nashej-rodiny-chem-po-vashemupahnet-rossija-sm.html (дата обращения 05.02.2016).

${ }^{4}$ Есть ли свой ЗАПАХ у нашей родины? [Электронный pecypc]. - URL: http://otvet.monavista.ru/ 410216/estsvoj-zapah-nashej-rodiny-vashemu-pahnet-rossiya/ (дата обращения 05.01.2016).

${ }^{5}$ Есть ли свой ЗАПАХ у нашей родины? [Электронный pecypc]. - URL: http://otvet.monavista.ru/ 410216/est-
}

березой, соснами, елью и морозной свежестью. Для меня Россия пахнет - сиренью, символом весны и расцьвета природы ${ }^{3}$; В России много лесов, а значит исконно русский запах это аромат русских деревьев, главный из коmopblx это запах березы ${ }^{4}$; Для меня запах России - это запах тайги. Высокие кедры, непроходимые буреломы, писк комаров, плеск рыбы в горных реках 5 .

К этой же группе можно отнести примеры, когда чисто русскими считаются запахи скошенной травы и сена: Летом по-особому пахнут свежие и скоченные травы. И кто вдыхал этот запах, тот никогда его не забудет и будет он ассоциироваться с бесконечньмми далями зеленых полей ${ }^{6}$;

2) запах мороза, морозной свежести, снега: Для меня запах Pодины, это морозная свежесть, когда выходишь зимой, (лучше на даче), с утра на улииу, и вдыхаешь полной грудью и чувствуешь, как пронзает всё тело, есть в этом что-то истинно Русское, русская зима. Ведь Россия самая большая и большая её часть северная, поэтому никакой другой запах не может быть, более Русским, чем эта морозная свежесть ${ }^{7}$; иентр России связан для меня с морозными ароматами ${ }^{8}$;

svoj-zapah-nashej-rodiny-vashemu-pahnet-rossiya/ (дата обращения 05.01.2016).

${ }^{6}$ Есть ли свой ЗАПАХ у нашей родины? [Электронный pecypc]. - URL: http://otvet.monavista.ru/ 410216/estsvoj-zapah-nashej-rodiny-vashemu-pahnet-rossiya/ (дата обращения 05.01.2016).

${ }^{7}$ Есть ли свой ЗАПАХ у нашей родины? [Электронный pecypc]. - URL: http://otvet.monavista.ru/ 410216/estsvoj-zapah-nashej-rodiny-vashemu-pahnet-rossiya/ (дата обращения 05.01.2016).

8 Чем по Вашему пахнет Россия [Электронный ресурс]. - URL: http://www.bolshoyvopros.ru/ questions/104852 1-est-li-svoj-zapah-u-nashej-rodiny-chem-po-vashemupahnet-rossija-sm.html (дата обращения 05.02.2016). 
Вестник Новосибирского государственного педагогического университета

2(30)2016 www.vestnik.nspu.ru ISSN 2226-3365

3) запах русских блюд (хлеба, блинов), молока: Россия пахнет хлебом из настоящей русской печи, блинами и душистым сеном ${ }^{9}$; пахнет домашним молоком, сметаной, пельменями ${ }^{10}$; Для меня Россия пахнет хлебом. Причем не какой-то булкой с ванилином, а нашим "бородинским" 11 ; И запах только что сваренной картошки, лука, селедочки и рюмки холодной водочки ${ }^{12}$;

4) запах сырой земли (после дождя или схода снега): Особый запах после схода снега, самой ранней весной. Запах влажный, земляной, какой-то пронизываюший, вызыввающий лёгкую тоску... ${ }^{13}$; запах мокрой земли в огороде, после дождя ${ }^{14}$;

5) запах дыма, горелой травы: Очень четкий, ни с чем не спутываемый, запах дыма из труб в деревне, из натапливаемьх дровами домов. И еще - запах сжигаемой травы весной, а также - сжигаемых листьев осенью ${ }^{15}$; моя Россия пахнет ... дымом - от сжигаемой

\footnotetext{
${ }^{9}$ Есть ли свой ЗАПАХ у нашей родины? [Электронный pecypc]. - URL: http://otvet.monavista.ru/ 410216/estsvoj-zapah-nashej-rodiny-vashemu-pahnet-rossiya/ (дата обращения 05.01.2016).

10 Чем по Вашему пахнет Россия [Электронный ресурс].

- URL: http://www.bolshoyvopros.ru/ questions/10485 21-est-li-svoj-zapah-u-nashej-rodiny-chem-po-vashemupahnet-rossija-sm.html (дата обращения 05.02.2016).

11 Аромат Родины // Известия. 2003. 17 октября [Электронный ресурс]. - URL: http://izvestia.ru/ news/282690 (дата обращения 06.02.2016).

12 Чем пахнет Родина для вас? [Электронный ресурс]. URL: http://www.askguru.ru/list.ghtml?ID= 485396 (дата обращения 06.02.2016).

13 Разговоры о самоопределении русского народа [Электронный ресурс]. - URL: http://holmogor.Livejou rnal.com/1490567.html (дата обращения 01.02.2016).

14 Запахи России. [Электронный ресурс] - URL: http://eva.ru/forum/topicmessages.htm?print=true \&topicId=3236643 (дата обращения 01.02.2016).

15 Чем же пахнет Россия? [Электронный ресурс]. - URL: http://aromatic.ucoz.ru/publ/chem_zhe_pakhnet_rossija/ 1-1-0-48 (дата обращения 05.02.2016).
}

травы весной ${ }^{16}$; Для меня самая главная ассоциация с родиной - вот этот запах. Посмотрите на фотографию. Прислушайтесь. Чувствуете? В ноздри проникает этот горьковатый дымок из печных труб ${ }^{17}$;

6) запах железнодорожного полотна, керамзита, шпал: Запах железнодорожного полотна, который сразу рождает мысль о бесконечных дорогах и путешествиях, когда можно долго-долго ехать по своей стране; Запах горячих шпал и запаха креозота... ${ }^{18}$; Креозотом (веществом, которым пропитывают деревянные шпалы). Очень люблю этот запах ${ }^{19}$;

7) запах метро, вагона поезда: возле станции когда идешь, на улице, прям такой запах-запах: тепльий и какой-то машинный. Не знаю точного названия, именно вот этот запах метро ${ }^{20}$; когда Москву вспоминаю, то почему-то сразу возникает запах метро, но мне он нравится, с детства приятные воспоминания об этих вагончиках и эскалаторах остались ${ }^{21}$.

16 Чем пахнет Россия? [Электронный ресурс]. - URL: https://otvet.mail.ru/question/8759453 (дата обращения 06.02.2016).

17 Одноклассники.ру [Электронный ресурс]. - URL: http://m.ok.ru/solikams/topic/64585715957811 (дата обращения 05.02.2016).

18 Чем пахнет Россия? [Электронный ресурс]. - URL: https://otvet.mail.ru/question/8759453 (дата обращения 06.02.2016).

19 Официальный форум Василия Васильевича Головачева [Электронный ресурс]. - URL: http://www. golovachev.ru/forum/showthread.php?t=35 (дата обращения 05.02.2016).

20 Аромания.ру [Электронный ресурс]. - URL: http://www.aromania.ru/index.php/topic/23640-31-маязапах-родины/page-4 (дата обращения 05.02.2016).

${ }^{21}$ Есть ли свой ЗАПАХ у нашей родины? [Электронный pecypc]. - URL: http://otvet.expert/est-li-svoy-zapah-unashey-rodini-em-po-vashemu-pahnet-rossiya-sm817723 (дата обращения 02.02.2016). 
Вестник Новосибирского государственного педагогического университета

2(30)2016 www.vestnik.nspu.ru ISSN 2226-3365

Последние две группы ассоциаций настолько частотны, что их повторяемость заставляет интернет-пользователей рефлексировать по этому поводу, связывать запахи с безграничным пространством России: Меня в этих ответах поразил, прежде всего, постоянно встречаюший образ запаха шпал, железной дороги, поезда, который неожиданно появляется посреди переживаний природы $и$ природных запахов. Россия пахнет бескрайним пространством ${ }^{22}$.

8) ассоциации, которые связывают Россию с материнским началом, эксплицируемые в том числе и путем сравнения запаха России с запахом матери или младенца: Чем же пахнет наша прекрасная Родина? Чувствуется еле уловимыцй, но такой родной и до боли знакомый запах матери ${ }^{23}$; Когда вечером выходишь на уличу тебя окружает множество ароматов: запах сырой земли, свежескоменной травы...запах матери и родного дома ${ }^{24}$; Запахи все время меняют друг друга, но все они вкусны и похожи на запах макуики ребенка ${ }^{25}$.

Представляется, что наиболее частотные одорические признаки России связываются с индивидуальным жизненным опытом человека. Поэтому они нередко обусловлены тем

\footnotetext{
${ }^{22}$ Холмогоров Е. СЧАСТЬЕ БЫТЬ РУССКИМ [Электронный pecypc]. - URL: http://www. specnaz.ru/article/?834 (дата обращения 05.02.2016).

${ }^{23}$ Есть ли свой ЗАПАХ у нашей родины? [Электронный pecypc]. - URL: http://otvet.expert/est-li-svoy-zapah-unashey-rodini-em-po-vashemu-pahnet-rossiya-sm817723 (дата обращения 05.02.2016).

24 Чем по Вашему пахнет Россия [Электронный ресурс]. - URL: http://www.bolshoyvopros.ru/ questions/1048521 -est-li-svoj-zapah-u-nashej-rodiny-chem-po-vashemupahnet-rossija-sm.html (дата обращения 05.02.2016).

${ }^{25}$ Есть ли свой ЗАПАХ у нашей родины? [Электронный pecypc]. - URL: http://otvet.expert/est-li-svoy-zapah-unashey-rodini-em-po-vashemu-pahnet-rossiya-sm817723 (дата обращения 02.02.2016).
}

эмоциональным и физическим состоянием говорящего, которые он испытывал в тот или иной момент перцепции.

По мнению субъектов высказываний, именно такое представление о запахах России сформировалось:

а) в детстве: ассоциацуии родом из детства: запах земляники на склонах холмов деревни Загорье ${ }^{26}$; для россиян мне кажется запах Родины - прежде всего запахи из детства, когда и сознание больше открыто и ассоцчиачии больие абстрактные ${ }^{27}$; Запах реки. Все летнее детство на ней провела ${ }^{28}$; Моя Родина попахивает тепльм навозцем, НО! в березах, цьветах, мазуте в перемешку с хмельными нотами. Это, видимо, последствия летнего деревенского детства моего ${ }^{29}$;

б) под влиянием русской художественной литературы: Запах России ещуе в свое время определил Иван Бунин в своем рассказе «Антоновские яблоки». Россия действительно пахнет спельми яблоками, скоченным сеном, ароматом земляники летом, весной пахнет сиренью и черемухой, зимой - морозной свежестью ${ }^{30}$. Это подтверждают и многочисленные примеры прецедентных высказываний, встречающихся выявленных кон-

26 Аромания.ру [Электронный ресурс]. - URL: http://www.aromania.ru/index.php/topic/23640-31-маязапах-родины/ (дата обращения 05.02.2016).

27 Аромания.pу [Электронный ресурс]. - URL: http://www.aromania.ru/index.php/topic/23640-31-маязапах-родины/ (дата обращения 05.02.2016).

${ }^{28}$ Аромания.ру [Электронный ресурс]. - URL: http://www.aromania.ru/index.php/topic/23640-31-маязапах-родины/ (дата обращения 05.02.2016).

${ }^{29}$ Аромания.ру [Электронный ресурс]. - URL: http://www.aromania.ru/index.php/topic/23640-31-маязапах-родины/page-2 (дата обращения 05.02.2016).

${ }^{30}$ Есть ли свой ЗАПАХ у нашей родины? [Электронный ресурс]. - URL: http://otvet.expert/est-li-svoyzapah-u-nashey-rodini-em-po-vashemu-pahnet-rossiyasm-817723 (дата обращения 02.02.2016). 
Вестник Новосибирского государственного педагогического университета

2(30)2016 www.vestnik.nspu.ru

ISSN 2226-3365

текстах: «Там русский дух... Там Русью пахнет». Это запах сена, злаков, хлеба русского, ягод и грибочков, а также полевых цветоч$\kappa о в^{31}$; С запахом дыма. "И дым Отечества нам сладок и приятен":- $)^{32}$;

в) на определённом значимом, нередко переломном этапе жизни: $B$ 90-е жизнь так развернулась, что я был фермером. Земля весной - вот это запах сердиевинной России ${ }^{33}$.

Иными словами, актуализация представлений о запахах России часто связана с модусом воспоминаний, а не с актуальными переживаниями. Нередко она осложняется дополнительными эмоциональными коннотациями: тоска по прошлому, грусть воспоминаний и под.: Запахи неизбывной русской грусти и неистребимой, вечной тоски; Вечной тоски, по чему - то, безвозвратно и навсегда ушедшему; Ускользающие, горестные запахи - так никогда и не сбывшихся надежд ${ }^{34}$.

Такой экспликации предшествует этап обобщения не только жизненного опыта, но и представлений о типично русских объектах. Ср.: И воздух такой чистый и свежий! Этот глубокий воздух имеет запах всех озер, от Байкала, до рек, морей. То соленоватый запах там, где Черное, Балтийское, Охотское моря, до пресный запах реки, как у Волги ${ }^{35}$. Возможно, что такие одорические ассоциации

\footnotetext{
31 Чем по Вашему пахнет Россия [Электронный реcypc]. - URL: http://www.bolshoyvopros.ru/ questions/1048521-est-li-svoj-zapah-u-nashej-rodinychem-po-vashemu-pahnet-rossija-sm.html (дата обращения 05.02.2016).

32 Чем пахнет Россия? [Электронный ресурс]. - URL: https://otvet.mail.ru/question/8759453 (дата обращения 06.02.2016).

33 Аромания.ру [Электронный ресурс]. - URL: http://www.aromania.ru/index.php/topic/23640-31-маязапах-родины/page-4 (дата обращения 05.02.2016).

${ }^{34}$ Есть ли свой ЗАПАХ у нашей родины? [Электронный pecypc]. - URL: http://otvet.expert/est-li-svoyzapah-u-nashey-rodini-em-po-vashemu-pahnet-rossiyasm-817723 (дата обращения 02.02.2016).
}

связаны не только с результатами перцептивного восприятия, но и отражают стереотипные представления о России в целом (ср. данные Русского ассоциативного словаря ${ }^{36}$ : на стимул Россия даются такие реакции, как мать (8), матушка (5), березка (1), лес (1); на стимул родина - мать (65), береза (1), березка (1), березки (1), березы (1), зелень (1), лес = поле = речка (1), поля = леса = реки (1), природа (1)). Похожие ассоциации возникают у интернетпользователей на стимул Россия: y меня c conками, с лесами, с полями, с реками, с историей; У меня, почему-то, Россия больше всего ассоичируется с березово-еловыми лесами... ${ }^{37}$ и пр.

Таким образом, можно предположить, что в сознании носителей языка за образом России закреплены скорее не реально физиологически ощущаемые запахи, а представления о русских реалиях, которые имеют отличающийся, явно выраженный (дblм, керамзит и пр.) и недостаточно выраженный, нелегко идентифицируемый запах (снег, береза и пр.). Запах представляется в двух плоскостях: перцептивном и когнитивном, ментальном, как объект восприятия и символ познания. Одорические впечатления порой подменяются ментальными (представлениями о визуально вос-

${ }^{35}$ Есть ли свой ЗАПАХ у нашей родины? [Электронный pecypc]. - URL: http://otvet.monavista.ru/ 410216/estsvoj-zapah-nashej-rodiny-vashemu-pahnet-rossiya/ (дата обращения 05.01.2016).

${ }^{36}$ Русский ассоциативный словарь: в 2-х т. / Ю. Н. Караулов, Г. А. Черкасова, Н. В. Уфимцева, Ю. А. Сорокин, Е. Ф. Тарасов. М. : Астрель; АСТ, 2002. Т. 1. От стимула к реакции: ок. 7000 стимулов. [Электронный pecypc]. - URL: http://tesaurus.ru/dict/dict.php, свободный (дата обращения 02.02.2016)

37 Что у вас в душе ассоциируется с Россией? [Электронный ресурс]. - URL: https://maxpark. com/user/ 91 1402693/content/301613 (дата обращения 05.02.2016). 
Вестник Новосибирского государственного педагогического университета

2(30)2016 www.vestnik.nspu.ru

ISSN 2226-3365

принимаемых объектах, например), тем самым можно наблюдать два семантических процесса: описание запаха (пахнет сеном); символизация одорических впечатлений (символическая метафора, или метафорический символ) (запах берез и просторов). Кроме того, наблюдаются многочисленные примеры синтестезии, когда одорическое восприятие «достраивает» сложившийся зрительный, звуковой, вкусовой или тактильный образ. Ср. Родина пахнет ароматами леса. Когда идешь по лесу с полной корзиной грибов, выходишь на лесную поляну и падаешь без сил на траву. Глазам открывается голубое небо, по которому лениво скользят облака, стрекочут кузнечики, поют птицы. И вперемешку с этими ощущениями накрывает тебя волна аромата: луговые травы, лесные изветы, запах нагретой на солние сосновой коры ${ }^{38}$.

Как показываются примеры, связь России с запаховыми признаками различных реалий носит преимущественно положительный характер. Происходит некоторая идеализация представлений. Россия в первую очередь - это родина, то, что остается от страны, когда из неё «вычитаются» география и политическое устройство, нечто «необъяснимое, что люди и любят больше всего другого» [23, с. 25].

Но нельзя не отметить и обратную ситуацию, когда одорические образы России носят сугубо негативный характер. Через типичные запахи говорящие выражают либо отрицатель-

${ }^{38}$ Есть ли свой ЗАПАХ у нашей родины? [Электронный pecypc]. - URL: http://otvet.monavista.ru/ 410216/estsvoj-zapah-nashej-rodiny-vashemu-pahnet-rossiya/ (дата обращения 05.01.2016).

39 Woman.ru [Электронный pecypc]. - URL: http://www.woman.ru/rest/medley8/thread/4328900/8/ (дата обращения 05.02.2016).

40 Чем пахнет Россия? [Электронный ресурс]. - URL: https://otvet.mail.ru/question/8759453 (дата обращения 06.02.2016). ное мнение относительно сложившейся ситуации в какой-либо области, либо высказывают критику на фоне представлений о других странах, эпохах и др.

Эталонами обонятельно воспринимаемых негативных запахов России становятся следующие:

1) запахи экскрементов: Абсолютно верно. Запах мочи вместе с табаком... Это запах советской власти для меня. Это - запах России $^{39}$;

2) запахи алкоголя, перегара: Россия - nерегар;

3) запахи нечистого тела, грязи: не обижайтесь братья русские, но [пахнет] запахом пота из подмышек! 40

Кроме того, именно данная группа насыщена одорическими метафорическими образами: можно наблюдать те явления, которые более всего не принимаются современным обществом. Это запахи:

1) тревожности и опасности: $У$ России запах постоянной тревожности и опасности, запах недоверия друг другу. Это основная составляюшая запаха России ${ }^{41}$;

2) бедности: Бедностью пока пахнет больше, чем благосостоянием и уверенностью $^{42}$; Экономический кризис принес в воздух страны необычный запах. Это не запах денег - это запах девальвации ${ }^{43}$;

3) перемен: Есть такая песня «Ветер перемен». По-моему, именно так и пахнет сейчас Россия. Откуда дует ветер и что он

41 Аромат Родины // Известия. 2003. 17 октября [Электронный ресурс]. - URL: http://izvestia.ru/ news/282690 (дата обращения 06.02.2016).

42 Аромат Родины // Известия. 2003. 17 октября [Электронный ресурс]. - URL: http://izvestia.ru/ news/282690 (дата обращения 06.02.2016).

43Запах девальвации // Рабкор. Интернет-журнал [Электронный ресурс]. - URL: http://rabkor.ru/columns/ editorials/2008/11/17/smells-like/ (дата обращения 05.02.2016). 
Вестник Новосибирского государственного педагогического университета

2(30)2016 www.vestnik.nspu.ru

ISSN 2226-3365

принесет, пока непонятно. Но запах перемен приятный и пока нам не очень привычны $\check{u ̆}^{44}$;

4) коррупции: Некоторые среди всех запахов России различают только зловонный запах коррупичии ${ }^{45}$;

5) конфессиональных доминант: Сегодня ряса, духовность и боевое кадило - это мейнстрим. Это теперь аромат большой политики и нашей новой идеологии! ${ }^{46}$

Ольфакторная метафора становится одним из адекватных средств, оценивающих неотъемлемые элементы современной российской жизни, что в целом соответствует характерным для современного дискурса «векторам опасности, агрессивности и тревожности» [24, c. 7]. Именно в данной группе в большей степени наблюдается взаимопроникновение ментальных и перцептивных структур.

Положительная и отрицательная «запаховые» оценки России имеют и еще один вектор противопоставления по шкале статичности и динамичности. Позитивно оцениваемые одорические признаки страны (природа, мороз, дымм и пр.) как бы находятся вне времени, они относительно постоянны, являются неотъемлемой чертой России, поскольку сформировались давно и именно поэтому первыми всплывают в сознании говорящих. Авторы высказываний скорее воспроизводят некие архетипические представления, но воплощают их в форме субъективного переживания, делают их личностными. Негативные же признаки чаще актуализируются в определенную эпоху, могут иметь «временный» характер, в силу социальных, политических, экономических изменений способны утрачиваться, менять полюс оценки. Ср. Я могу только надеяться, что скоро запах перемен превратится в запах свободы, богатства и сильи ${ }^{47}$.

Таким образом, слова с семой запах участвуют не только в процессе языкового кодирования ситуации ольфакторного восприятия, но и выступают в роли культурно значимых ориентиров, способствующих познанию окружающей действительности. Образ России в сознании носителей языка оказывается биполярным, обусловленным своеобразием культуры, историческими традициями, лингвокультурными характеристиками, национальным менталитетом, а также особенностями политической культуры, политического поведения носителей языка.

\section{СПИСОК ЛИТЕРАТУРЫ}

1. Мамцева В. В. К вопросу о вербализации концепта «запах» в художественной литературе // Вестник Чувашского государственного педагогического института им. И. Я. Яковлева. 2015. - № 2 (86). - С. 101-106.

2. Классен К., Хоувз Д., Синнотт Э. Значение и власть запаха // Ароматы и запахи в культуре / сост. О. Б. Вайнштейн. - М.: Новое литературное обозрение, 2003. - Кн.1.- С. 43-52.

\footnotetext{
44 Аромат Родины // Известия. 2003. 17 октября [Электронный ресурс]. - URL: http://izvestia.ru/ news/282690 (дата обращения 06.02.2016).

${ }^{45}$ Есть ли свой ЗАПАХ у нашей родины? [Электронный pecypc]. - URL: http://otvet.expert/est-li-svoy-zapah-unashey-rodini-em-po-vashemu-pahnet-rossiya-sm817723 (дата обращения 02.02.2016).
}

46 Запах Родины [Электронный ресурс]. - URL: https://rufabula.com/articles/2013/10/23/smells-like-kinspirit (дата обращения 03.02.2016).

47 Аромат Родины // Известия. 2003. 17 октября [Электронный ресурс]. - URL: http://izvestia.ru/ news/282690 (дата обращения 06.02.2016). 
Вестник Новосибирского государственного педагогического университета

2(30)2016 www.vestnik.nspu.ru ISSN 2226-3365

3. Шилина А. В. Лингвокультурологический аспект изучения лексики ольфакторного восприятия // Актуальные проблемы гуманитарных и естественных наук. - 2013. - № 6. - С. 255-257.

4. Вайнштейн О. Грамматика ароматов // Ароматы и запахи в культуре / сост. О. Б. Вайнштейн. - М.: Новое литературное обозрение, 2003. - Кн. 1. - С. 5-13.

5. Кирсанова Р. Аромат родного дома и запах счастья // Ароматы и запахи в культуре / Сост. О. Б. Вайнштейн. - М.: Новое литературное обозрение, 2003. - Кн. 2. - С. 270-279.

6. Колупаева А. А. Национальные особенности концепта запах в русском языке // Вестник Тамбовского университета. Серия: Гуманитарные науки. - 2008. - № 7 (63). - С. 86-89.

7. Павлова Н. С. Запах города: вчера и сегодня (функционирование ольфакторной лексики в тексте) // «Функциональная семантика, семиотика знаковых систем и методы их изучения». I Новиковские чтения: материалы Международной научной конференции (Москва, 5-6 апреля 2006 г.). - М.: Изд-во РУДН, 2006. - С. 252-256.

8. Рогачева Н. А. Ольфакторное пространство русской поэзии конца XIX - начала XX вв.: проблемы поэтики: монография. - Тюмень: Изд-во Тюмен. гос. ун-та, 2010. - 404 с.

9. Старостина Ю. А. Концепты «запах» и «красота» в романе П. Зюс-кинда «Парфюмер. История одного убийцы» // Известия Волгоградского государственного педагогического университета. Серия: Филологические науки. - 2009. - № 7 (41). - С. 164-169.

10. Трипольская Т. А. Интерпретационный потенциал концепта «запах» // Новая Россия: новые явления в языке и науке о языке: матер. Всерос. науч. конф. 14-16 апреля 2005 г. Екатеринбург, Россия. - Екатеринбург: Изд-во Урал. ун-та, 2005. - С. 35-43.

11. Miller G. A., Johnson-Laird P. N. Language and Perception. - Cambridge. Mass.: Harvard Univ. Press, 1979. $-760 \mathrm{p}$.

12. Engen T. The Perception of Odors. - N.-Y.: Academic Press, 1982. -202 p.

13. Clark H. H., Carpenter P. A., Just M. A. On the Meeting of Semantics and Perception // Visual Information Processing. - N.-Y., London: Academic Press, 1973. - P. 311-383.

14. Виноградов В. В. Основные типы лексических значений // Вопросы языкознания. - 1953. № 5. - C. 3-29

15. Потебня А. А. Из записок по русской грамматике // Звегинцев В. А. История языкознания XIX-XX веков в очерках и извлечениях. - М.: Просвещение, 1964. - Ч. 1. - С. 142-169.

16. Карасик В. И. Языковой круг. Личность, концепты, дискурс. - Волгоград: Перемена, 2002. URL: http://www.studfiles.ru/preview/1806336/page:10/ (дата обращения: 27.01.2016).

17. Падучева Е. В. Семантические исследования: Семантика времени и вида. Семантика нарратива. - М.: Школа «Языки русской культуры», 1996. - 464 с.

18. Бартминьский Е. Языковой образ мира: очерки по этнолингвистике. - М., 2005. - 512 с.

19. Кирилина А. В. Гендер: лингвистические аспекты. - М.: Институт социологии РАН, 1999. $-155 \mathrm{c}$.

20. Щекотихина И. Н. Стереотип: аспекты и перспективы исследования // Вестник Ленинградского государственного университета им. А. С. Пушкина. - 2008. - № 5 (19). - С. 69-80.

21. Прохоров Ю. Э. Национальные социокультурные стереотипы речевого общения и их роль в обучении иностранному языку иностранцев. - М.: ЛКИ, 2003. -224 с.

22. Красных В. В. Этнопсихолингвистика и лингвокультурология. - М.: Гнозис, 2002. - 284 с.

23. Воркачев С. Г. «Родина с нами»: идея патриотизма в русской лингвокультуре // Этногерменевтика и когнитивная лингвистика. - Landau: Verlag Empirische Pedagogik, 2007. - C. 24-44.

24. Чудинов А. П. Россия в метафорическом зеркале: когнитивное исследование политической метафоры (1991-2000). - Екатеринбург: УрГПУ 2001. - 238 с. 
Novosibirsk State Pedagogical University Bulletin

2016, Vol. 6, No. 2 http://en.vestnik.nspu.ru

ISSN 2226-3365

DOI: 10.15293/2226-3365.1602.04

Basalaeva Elena Gennadjevna, Candidate of Philological Sciences, Associate Professor, Department of Language Theory and Intercultural Communication, Novosibirsk State Pedagogical University, Novosibirsk, Russian Federation

ORCID iD 0000-0003-2830-0294

E-mail: lena.bas@mail.ru

\title{
NATIONAL AND CULTURAL PECULIARITIES OF OLFACTORY LEXIS
}

\begin{abstract}
The article analyzes various ways of describing reality in online discourse in the light of olfactory perception. Olfactory perception is one of the most important steps in the development of human mind, in comprehending of the world around us. The attention to the studies of the olfactory nominative space is increasing nowadays. At the same time some questions of its national and cultural peculiarity, remain open. Anchoring of stable olfactory associations to this or that object forming a certain cultural stereotype is among them. Our study is an attempt to describe the manifestation of the cultural component in 'odour-focused' segments containing references to 'one's own' area (a country, city, village, etc.) on the material extracted from Internet discourse. The analysis can reveal the stereotyped olfactory representations, depending on the olfactory cultural standards and their personal perception by an individual speaker. Thus, on the one hand, the image of the country for the speaker is a positively coloured field of associations formed by such stereotyped odours, as the smells of nature, frost, bread, mother etc., on the other hand, the negative assessments can also appear, often as a result of metaphorical rethinking (the smell of poverty). Odourative images are often replaced by mental ones, thus two different semantic processes can be observed: a description of an odour and symbolization of olfactory impressions. The words with the seme of smell are involved not only in the process of language coding of olfactory perception, but also play the role of culturally significant landmarks that contribute to the knowledge of reality.
\end{abstract}

\section{Keywords}

Lexical meaning, lexis olfactory perception, national and cultural component, Internet discourse.

\section{REFERENCES}

1. Mamceva V. V. Verbalization of the concept of "smell" in fiction. I. Yakovlev Chuvash State Pedagogical University Bulletin, 2015, no. 2 (86), pp. 101-106. (In Russian)

2. Classen C., Howes D., Synnott A. The value and power of smell. Aromas and smells in culture. Moscow, New Literary Observer Publ., 2003, vol. 1, pp. 43-52. (In Russian)

3. Shilina A.V. Lingvokulturologichesky aspect of studying vocabulary olfactory perception. Actual problems of the humanities and natural sciences, 2013, no. 6, pp. 255-257. (In Russian)

4. Vajnshtejn O. Grammar of smells. Aromas and smells in culture. Moscow, New Literary Observer Publ., 2003, vol. 1, pp. 5-13. (In Russian)

5. Kirsanova R. The aroma of home and the smell of happiness. Aromas and smells in culture. Moscow, New Literary Observer Publ., 2003, vol. 2, pp. 270-279. (In Russian)

6. Kolupaeva A. A. National characteristics smell concept in Russian. Tambov University Review. Series: Humanities, 2008, no. 7 (63), pp. 86-89. (In Russian) 
7. Pavlova N. S. The smell of the city yesterday and today (functionolfactory vocabulary in the text). "Functional semantics, semiotics of sign systems and methods of their study". I Novikov reading: Proceedings of the International Scientific Conference (Moscow, 5-6 April 2006). Moscow, RUDN University Publ., 2006, pp. 252-256. (In Russian)

8. Rogacheva N. A. Olfactory space Russian poetry of the end of XIX - early XX centuries: poetics problems. Tyumen, Tyumen State University Publ., 2010, 404 p. (In Russian)

9. Starostina Yu. A. The concepts of "smell" and "beauty" in the novel P. Süsskind "Perfume. The story of a Murderer». Volgograd State Pedagogical University Bulletin. Philology, 2009, no. 7 (41), pp. 164-169. (In Russian)

10. Tripolskaya T. A. Express modelling the mental structure "odour perception" in Russian language picture of the world. Interpretational problems of linguistics: the types of perceptions and their linguistic embodiment. Novosibirsk, Novosibirsk State Pedagogical University Publ., 2013, pp. 50 61. (In Russian)

11. Miller G. A., Johnson-Laird P. N. Language and Perception. Cambridge. Mass., Harvard Univ. Press Publ., 1979, 760 p.

12. Engen T. The Perception of Odors. N.-Y., Academic Press Publ., 1982, 202 p.

13. Clark H. H., Carpenter P. A., Just M. A. On the Meeting of Semantics and Perception. Visual Information Processing. N.-Y. London, Academic Press, 1973. pp. 311-383.

14. Vinogradov V. V. The main types of lexical meanings. Voprosy Jazykoznanija, 1953, no. 5, pp. 329. (In Russian)

15. Potebnja A.A. From the notes on Russian grammar. Zvegintsev $V$. A. History of linguistics $X I X-X X$ centuries in the essays and extracts. Part 1. Moscow, Prosveshhenie Publ., 1964, pp.142-169. (In Russian)

16. Karasik V.I. Linguistic Circle. Person, concepts, discourse. Volgograd, Peremena Publ., 2002. (In Russian). Available at: http://www.studfiles.ru/preview/1806336/page:10/ (accessed 27.01.2016).

17. Paducheva E. V. Semantic Research: The semantics of the time and type. The semantics of the narrative. Moscow, LRC Publishing House Publ., 1996. 464 p. (In Russian)

18. Bartmin'skij E. Language Image of the World: Essays on ethnolinguistics. Moscow, 2005, 512 p. (In Russian)

19. Kirilina A.V. Gender: linguistic aspects. Moscow, Institute of Sociology of the Russian Academy of Sciences Publ., 1999, 155 p. (In Russian)

20. Shhekotihina I. N. Stereotype: aspects and perspectives of research. Pushkin Leningrad State University Bulletin, 2008, no. 5 (19), pp. 69-80. (In Russian)

21. Prohorov Ju. Je. National socio-cultural stereotypes of verbal communication and their role in foreign language teaching foreigners. Moscow, LKI Publ., 2003, 224 p. (In Russian)

22. Krasnyh V.V. Ethnopsycholinguistics and cultural linguistics. Moscow, Gnozis Publ., 2002, 284 p. (In Russian)

23. Vorkachev S. G. "Homeland is with us": the idea of patriotism in Russian linguoculture. Etnohermeneutics and cognitive linguistics. Landau, Verlag Empirische Pдdagogik Publ., 2007. pp. 24-44. (In Russian)

24. Chudinov A. P. Russia in a metaphorical mirror: cognitive study of political metaphors (19912000). Ekaterinburg: Ural State Pedagogical University Publ., 2001, 238 p. (In Russian). 